\title{
METHANE FLUX FROM A SUBTROPICAL RESERVOIR LOCATED IN THE FLOODPLAINS OF RIVER YAMUNA, INDIA
}

\author{
BANSAL, S. $^{1}$ - CHAKRABORTY, M. ${ }^{2}-$ KATYAL, D. ${ }^{1}-$ GARG, J.K..${ }^{* 1}$ \\ ${ }^{1}$ University School of Environment Management, Guru Gobind Singh Indraprastha University, \\ Dwarka, Delhi 110078, India \\ ${ }^{2}$ CSIR - National Physical Laboratory, New Delhi 110012, India \\ *Corresponding author: \\ e-mail: gargjk@gmail.com; phone: +91-11-2530-2371; fax: +91-11-2530-2111
}

(Received $7^{\text {th }}$ Jan 2015; accepted $27^{\text {th }}$ Feb 2015)

\begin{abstract}
Tropical and subtropical reservoirs are considered to be a strong anthropogenic source of methane $\left(\mathrm{CH}_{4}\right)$ emissions worldwide due to high temperature, augmented carbon and nutrient loadings. Thus, $\mathrm{CH}_{4}$ emission estimation from tropical/subtropical reservoirs is critical for preparation of green house gas emission budgets. The Present study estimates $\mathrm{CH}_{4}$ flux from a subtropical freshwater manmade Okhla reservoir located on the river Yamuna, National Capital Region, India. Results showed that Okhla reservoir transformed into a potential $\mathrm{CH}_{4}$ emission source after flooding as the $\mathrm{CH}_{4}$ flux increased by 3.81 orders of magnitude with a net contribution of $171.96 \mathrm{mgm}^{-2} \mathrm{~d}^{-1}$. Enhanced $\mathrm{CH}_{4}$ flux is primarily attributed to elevated organic and nutrient loadings to reservoir via river's inflow water, high percentage of shallow areas and presence of dense aquatic vegetation mainly Eichhornia crassipes and Typha angustifolia. These aquatic weeds not only facilitate vascular $\mathrm{CH}_{4}$ transport but also provide substantial amounts of biomass for methanogens to generate $\mathrm{CH}_{4}$. Results also revealed that the summer season exhibited significantly higher $\mathrm{CH}_{4}$ flux (Kruskal-Wallis H-Test; $\mathrm{p}<0.05$ ) as compared to monsoon and winter seasons due to prevalence of more favorable water and soil conditions for $\mathrm{CH}_{4}$ emissions including temperature, redox potential, water depth, dissolved oxygen, biological oxygen demand and plant biomass.
\end{abstract}

Keywords: artificial wetlands, semi-static chamber technique, macrophytes, total organic carbon, eutrophic conditions

\section{Introduction}

Reservoirs principally represent artificial wetlands which are used for storage, regulation and control of water resources. Construction of reservoirs through interrupting the river by dams and barrages, refurbish the entire lotic water system (river system) into the lentic water system (reservoirs) leading to pronounced impacts on physico-chemical characteristics, nutrient loading besides floral and faunal composition of the river water. Organic enrichment after the impoundment results in anaerobiosis that supports the generation and release of green house gases including methane $\left(\mathrm{CH}_{4}\right)$, carbon dioxide $\left(\mathrm{CO}_{2}\right)$ and nitrous oxide $\left(\mathrm{N}_{2} \mathrm{O}\right)$ etc. due to the increased decomposition of biomass and nutrient loadings of carbon, nitrogen and phosphorus.

Methane $\left(\mathrm{CH}_{4}\right)$ emissions from the reservoirs vary widely depending upon reservoir specific characteristics including surface area, age, shape and depth of the reservoir, water residence time in the reservoir, water quality, organic loading by tributaries and rivulets, surface flow from the surrounding areas, the quantity and quality of vegetation of flooded and surrounding areas (St. Louis et al., 2000; Guerin et al., 2006).

Reservoirs also show extensive variations in $\mathrm{CH}_{4}$ emissions due to changes in the local climate. Guerin et al. (2006) estimated $\mathrm{CH}_{4}$ emissions from three tropical 
reservoirs including Petit Saut reservoir (France), Balbina and Samuel reservoir (Brazil) in the range of $33.60-80 \mathrm{mgm}^{-2} \mathrm{~d}^{-1}$. Likewise, Karin Grandin (2012) calculated $\mathrm{CH}_{4}$ emissions from three Brazilian tropical reservoirs consisting of Funil reservoir, Santo Antonio reservoir and Tres Marais reservoir. The total measured $\mathrm{CH}_{4}$ fluxes in three reservoirs varied from 5.28 to $1155.36 \mathrm{mgm}^{-2} \mathrm{~d}^{-1}$ with mean flux of $36.96 \mathrm{mgm}^{-2} \mathrm{~d}^{-1}$ from all the three reservoirs. Tremblay et al. (2005) did $\mathrm{CH}_{4}$ emission studies for boreal reservoirs of northern Canada reporting that $\mathrm{CH}_{4}$ flux varied from 0 to $20 \mathrm{mgm}^{-2} \mathrm{~d}^{-1}$. Soumis et al. (2004) focused on the estimation of $\mathrm{CH}_{4}$ emissions from temperate reservoirs of the western United States and measured diffusive $\mathrm{CH}_{4}$ flux from 3.20 to $9.50 \mathrm{mgm}^{-2} \mathrm{~d}^{-1}$. Wang et al. (2013) reported flux values for two subtropical reservoirs in Taiwan including Liyutan Reservoir $\left(\mathrm{CH}_{4}\right.$ flux: 0.72 to $\left.28.80 \mathrm{mgm}^{-2} \mathrm{~d}^{-1}\right)$ and $2^{\text {nd }}$ Baoshan Resevoir $\left(\mathrm{CH}_{4}\right.$ flux: 0.72 to $\left.9.60 \mathrm{mgm}^{-2} \mathrm{~d}^{-1}\right)$. These studies apparently show that reservoirs in the tropical and subtropical regions show higher $\mathrm{CH}_{4}$ emissions as compared to temperate and boreal reservoirs due to nutrient enrichment, high carbon loadings and increased water temperatures. St. Louis et al. (2000) estimated that $90 \%$ of global reservoir $\mathrm{CH}_{4}$ emissions were from reservoirs in tropical regions; however Bastviken et al. (2011) attribute freshwater ecosystems located in tropics contribute about $49 \%$ of the total $\mathrm{CH}_{4}$ emissions. Consequently, considering varying reservoir characteristics and local climate, more intensive work is required to quantify the contribution of tropical and subtropical reservoirs to $\mathrm{CH}_{4}$ budgets.

In India, a large number of dams and barrages have been constructed since independence for storage, flood control, irrigation and hydro-electricity generation. These man-made water storages can significantly contribute towards $\mathrm{CH}_{4}$ emission. Surprisingly, most of the published data related to $\mathrm{CH}_{4}$ fluxes in India mainly comprises $\mathrm{CH}_{4}$ emissions from lakes and rivers such as Verma et al. (2002) from Vembanad Lake, Purvaja et al. (2004) from unpolluted mangrove, Rajkumar et al. (2008) from Adyar River, Khoiyangbam et al. (2008) from Lakshmi and Antiya Lake, Mallick and Dutta (2009) in the Bhalsawa Lake. Methane $\left(\mathrm{CH}_{4}\right)$ emission studies from the reservoirs are highly sporadic. Narvenkar G. et al. (2013) estimated dissolved $\mathrm{CH}_{4}$ emissions from eight reservoirs and measured surface water $\mathrm{CH}_{4}$ concentrations in the range of $0.0028-$ $0.305 \mu \mathrm{M}$. It is apparent that the present study is the first comprehensive dataset on airwater interface $\mathrm{CH}_{4}$ flux from an Indian reservoir i.e., Okhla reservoir located in floodplains of river Yamuna on Delhi-Uttar Pradesh border, India. Current study attempts to quantify and seasonally describe the $\mathrm{CH}_{4}$ flux for the Okhla reservoir as it is an important fresh water subtropical reservoir heavily infested by various types of truly aquatic, amphibious and terrestrial vegetation with extreme anthropogenic pressure in terms of high pollutant and organic loadings from nearby urban, agricultural and industrial areas.

\section{Material and Methods}

\section{Study Area}

Present research work has been carried out in the Okhla reservoir which is a manmade fresh water reservoir created after the construction of Okhla Barrage on river Yamuna on 8th May, 1990 for the purpose of irrigation and flood control in the surrounding areas. Okhla reservoir was notified as Okhla Bird Sanctuary (OBS) by the Uttar Pradesh government under the Wildlife (Protection) Act, 1972 (Management Plan for Okhla Bird Sanctuary, 2011-2021). The most important sources of input water that 
enters the reservoir includes Yamuna water released after Wazirabad Barrage, Hindon water discharged from Hindon Barrage and runoff generated from Delhi area. The major outflows include water released into the Agra canal and downstream into river Yamuna heading towards Uttar Pradesh.

Okhla reservoir is under extreme anthropogenic pressure due to high load of pollutants discharged into it from the nearby residential, agricultural and industrial areas through river's inflow water (Yamuna river and Hindon river). Yamuna water entering the sanctuary is highly polluted due the waste discharges from 19 major drains including Najafgarh drain between Okhla and Wazirabad. Okhla reservoir also receives agricultural and industrial waste from Uttar Pradesh through Hindon river via Hindon Cut.

Even though the Okhla reservoir receives high pollution load and is greatly influenced by human disturbances, it provides breeding ground to a large number of species of birds, reptiles, mammals, amphibians and is occupied by a variety of aquatic, amphibious and terrestrial plants including Eichhornia crassipes, Pistia stratiotes, Typha angustifolia, Kyllinga squamulata, Alternanthera sessilis etc. Thus, this reservoir represents a human intervened sub-tropical freshwater artificial wetland which can act as one of potential source of $\mathrm{CH}_{4}$ emissions predominantly due to high pollution load and heavy vegetation infestation. Major features of Okhla reservoir are enlisted in Table 1 whereas the location of the study site is shown in Figure 1.

Table 1. Main characteristics of Okhla Reservoir, Gautam Budh Nagar, National Capital Region, India

\begin{tabular}{ll}
\hline Characteristics & Reservoir \\
\hline Country & India \\
Location & Delhi-Utttar Pradesh Border, National Capital \\
& Region (NCR) \\
Date of Creation/ approximate age & $8^{\text {th }}$ May, $1990 / \sim 24$ years \\
Geographic Location & Latitude: $28^{\circ} 32^{\prime} 56.3^{\prime \prime} \mathrm{N}$ and Longitude: $77^{\circ} 18^{\prime}$ \\
& $56.6^{\prime \prime}$ E from Delhi site and Latitude: $28^{\circ} 32^{\prime} 43.5^{\prime}$ \\
& $\mathrm{N}$ and Longitude: $77^{\circ} 18^{\prime} 41.7^{\prime}$ E from Uttar Pradesh \\
& site \\
Altitude & $200 \mathrm{~m}$ \\
Area & 400 hectares (flooded area: 370 hectares; roads and \\
Annual Rainfall & bunds: 30 hectares) \\
Water Depth & $660-670$ mm \\
& $0.15-3 \mathrm{~m}$ (water expanse and its depth varies with \\
\hline Source: Management Plan for Okhla Bird Sanctuary (2011-2021).
\end{tabular}

\section{Sample collection and analysis}

To assess the net contribution of the Okhla reservoir to $\mathrm{CH}_{4}$ flux, $\mathrm{CH}_{4}$ emission estimation was accomplished for two different zones including exposed soil zone (ESZ) and water zone (WZ). Water surface $\mathrm{CH}_{4}$ concentration in any reservoir is mainly described as a function of soil sediments that gets impounded after flooding the 
reservoir as the methane is generally derived from the organic matter present in terrestrial soils inundated during impoundment (Kemens et al. 2011).

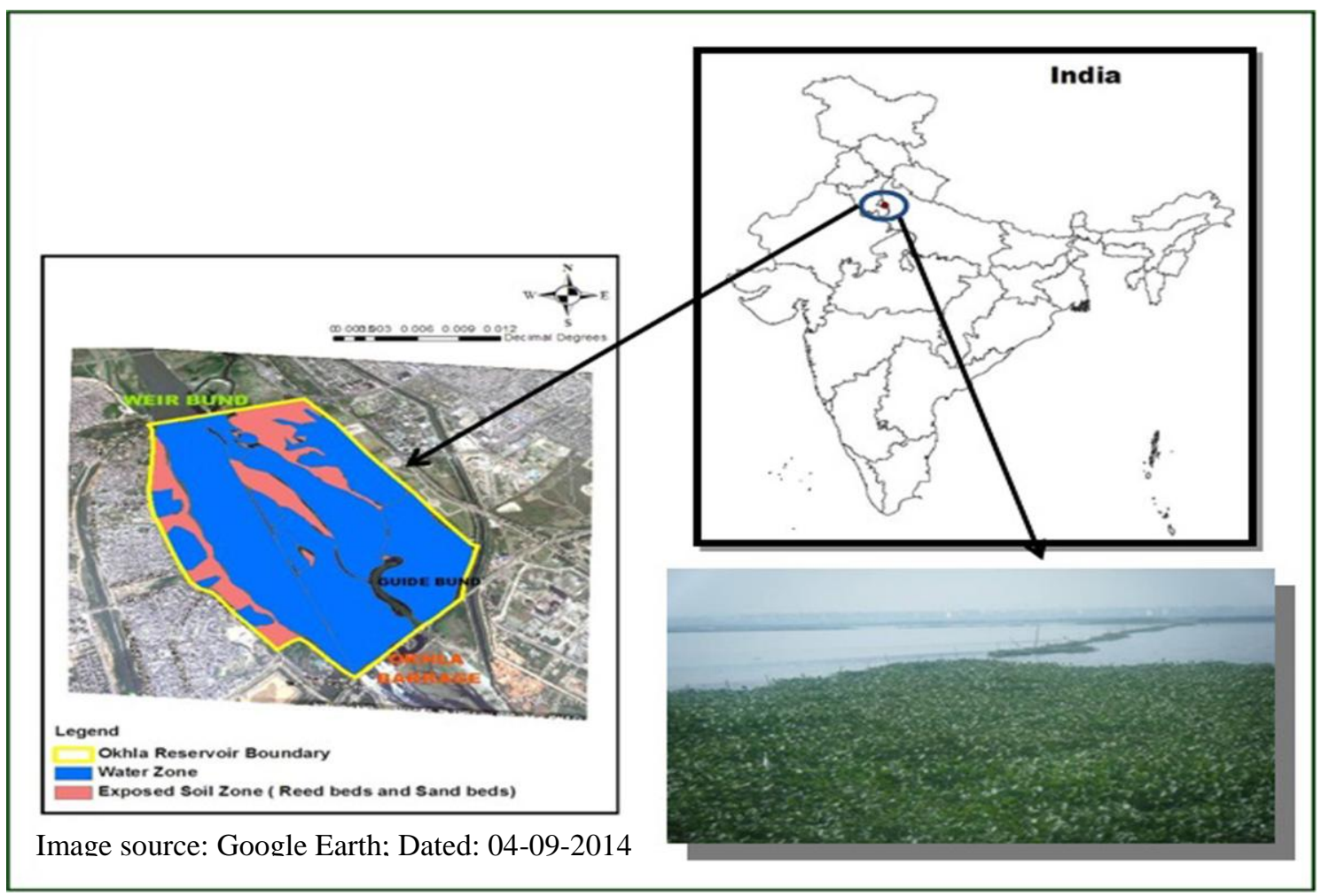

Figure 1. Map to show location of Okhla Reservoir, Gautam Budh Nagar, National Capital Region, India

Therefore, terrestrial soil present in the reservoir (ESZ) was assumed as the reference site for pre-impoundment $\mathrm{CH}_{4}$ flux estimation whereas $\mathrm{WZ}$ was selected for postimpoundment $\mathrm{CH}_{4}$ flux calculation. The ESZ mainly included the water-logged soil and terrestrial soil (reed beds and sand beds) present inside and along the reservoir periphery/edges. To consider for inhomogeneity of water body i.e., shallow and deep stratified reservoir areas, WZ was further sub-divided into two zones i.e., shallow water zone (SWZ; depth < $200 \mathrm{~cm}$ ) and deep water zone (DWZ; depth $\geq 200 \mathrm{~cm}$ ). $\mathrm{CH}_{4}$ emissions estimations were done on seasonal basis i.e., monsoon (July -October 2010), winter (November-March 2010-2011) and summer season (April -June 2011) deploying semi-static chamber technique.

\section{Gas fluxes: sampling and analysis}

For each zone, $\mathrm{CH}_{4}$ gas sampling was made using semi-static chamber technique (Figure 2) which measures the total $\mathrm{CH}_{4}$ emissions including diffusive as well as ebullitive $\mathrm{CH}_{4}$ emission. To collect gas samples from water and soil surface, perspex chambers with dimensions $36.25 \mathrm{~cm} \times 33.00 \mathrm{~cm} \times 53.75 \mathrm{~cm}$ (Length $\times$ Breadth $\times$ Height) were used. Homogenous mixing of air inside the chambers was maintained through battery-operated fans. Gas samples were collected in pre-evacuated $50 \mathrm{ml}$ air tight plastic syringes through a vent provided at the top of the chamber. For each zone, 
gas sampling was carried out twice a day and thrice in a season in 3-4 replicates at the intervals of $0,15,30,45$ and $60 \mathrm{~min}$.
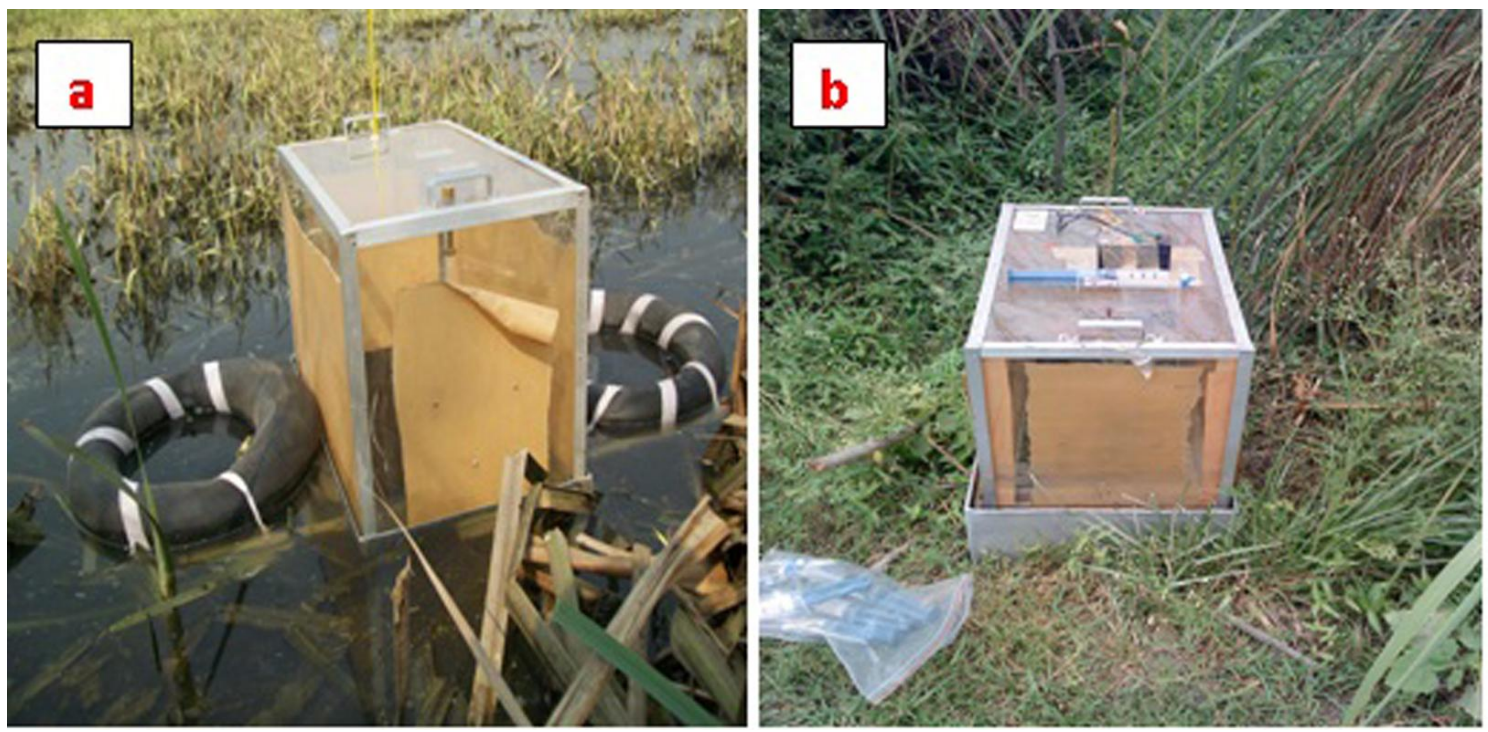

Figure 2. Semi-static chamber technique to collect gas samples from a) air-water interface, and b) soil surface at Okhla reservoir

Gas chromatograph (model no. 6890, Agilent Technologies, USA) fitted with Flame ionized detector (FID) and wide bore HP-PLOT Q capillary column was used to analyze $\mathrm{CH}_{4}$ gas samples. The column, inlet and detector were maintained at temperatures of 45 , 250 and $250^{\circ} \mathrm{C}$ respectively. $\mathrm{CH}_{4}$ peak was identified at retention time of $2.4 \mathrm{~min}$. The column flow was maintained at $3.0 \mathrm{ml} / \mathrm{min}$ with the spilt ratio of $1 \mathrm{ml} / \mathrm{min}$. Concentration of $\mathrm{CH}_{4}$ gas in the samples was calculated by calibrating gas


from MAINZ, Germany) and $10.1 \pm 0.1 \mathrm{ppmv} \mathrm{CH}_{4}$ in nitrogen (procured from Spectra Gas, USA). Daily gas concentration in the chambers was estimated by applying the temporal decrease and increase of $\mathrm{CH}_{4}$ mixing ratios inside the chambers following the equation mentioned below (Singh et al., 1998; Chakraborty et al., 2011):

$$
\mathrm{CH}_{4}\left(\mathrm{mg} \mathrm{m}^{-2} \mathrm{~d}^{-1}\right)=\left[\left(\mathrm{BV}_{\mathrm{STP}} \times \mathrm{C}_{\mathrm{CH} 4} \times \mathrm{M} \times 1000 \times 60\right) /\left(10^{6} \times 22400 \times \mathrm{A} \times \mathrm{t}\right)\right] \times 24
$$

\section{Where}

$\mathrm{BV}_{\mathrm{STP}}\left(\right.$ Box Air Volume in $\mathrm{cm}^{3}$ at standard temperature and pressure $)=$ $(\mathrm{BV} \times \mathrm{BP} \times 273) /[(273+\mathrm{T}) \times 760]$

$\mathrm{BV}$ (Box volume) for water surface $=(\mathrm{H}-\mathrm{h}) \times \mathrm{L} \times \mathrm{W}-($ volume of biomass inside the chamber); $\mathrm{H}=$ chamber height in $\mathrm{cm}, \mathrm{h}=$ water level above the channel $\mathrm{cm} ; \mathrm{L}=$ chamber length in $\mathrm{cm} ; \mathrm{W}=$ chamber width in $\mathrm{cm}$

BV (Box volume) for soil surface $=(\mathrm{H}+\mathrm{h}) \times \mathrm{L} \times \mathrm{W}-($ volume of biomass inside the chamber); $\mathrm{H}=$ chamber height in $\mathrm{cm}, \mathrm{h}=$ channel height above soil surface in $\mathrm{cm} ; \mathrm{L}=$ chamber length in $\mathrm{cm} ; \mathrm{W}=$ chamber width in $\mathrm{cm}$

$\mathrm{M}=$ molecular weight of $\mathrm{CH}_{4}$

$\mathrm{BP}=$ barometric pressure $(\mathrm{mm} \mathrm{Hg})$ at the time of sampling 
$\mathrm{T}=$ chamber air temperature at the time of sampling in Kelvin $\left(\mathrm{K} ; 273+\right.$ temp in $\left.{ }^{\circ} \mathrm{C}\right)$

$\mathrm{C}_{\mathrm{CH} 4}=$ change in $\mathrm{CH}_{4}$ concentration in $(\mathrm{ppm})$ from $0 \mathrm{~min}$. sampling to the $\mathrm{t} \min$. sampling

$\mathrm{A}=$ wetland area covered by the chamber in $\mathrm{m}^{2}$.

\section{Water and soil quality}

Water samples were collected in 2 litre bottles from the well mixed zone of $0.3 \mathrm{~m}$. Water DO (Dissolved oxygen), Eh (Redox potential), pH and WT (Water temperature) were predicted in the field at the time of gas sampling deploying portable DO, Eh and pH meter (model: HACH-HQ30D) and portable Infra Red Thermometer (model: OAKTON: Infra Pro ${ }^{\circledR}$ 5) respectively. Water depth (WD) was estimated using a wellmarked wooden pole. Phosphate $\left(\mathrm{PO}_{4}{ }^{3-}\right)$, Nitrate $\left(\mathrm{NO}_{3}{ }^{-}\right)$, and BOD (Biological oxygen demand) were analyzed using the standard methods for analysis of water and waste water (APHA, 2005). TOC (Total organic carbon) was estimated using TOC analyzer which consisted of two units, namely, a) Digester (model: HACH-DRB 200) for digesting water samples, and b) Calorimeter (model: HACH-DR 900) for taking readings.

Soil samples were collected in air tight plastic vials using soil tube auger (Singh et al., 1999) at the depth of $22.08 \mathrm{~cm}$ to analyze various soil quality parameters. Soil Eh, soil $\mathrm{pH}$, and soil temperature (ST) were estimated following the same analytical methods as used in case of water analysis. Soil organic carbon (SOC) was analyzed using Walkley and Black Method (Walkley and Black, 1934).

GARMIN etrex -12 channel Global Positioning System was used to mark the location of each sampling point in the field. The floral compositions were analyzed using a Quadrat Method (APHA, 2005) deploying quadrat of $1 \times 1 \mathrm{~m}^{2}$. The plant biomass was measured by harvesting plant species from $1 \times 1 \mathrm{~m}^{2}$ plots. Fresh weight of each plant sampled was noted in the field and then oven dried at $105^{\circ} \mathrm{C}$ over night to obtain the dry weight.

\section{Statistical analysis}

Temporal variability in $\mathrm{CH}_{4}$ emissions was evaluated using non-parametric statistics in both ESZ and WZ (Kruskal-Wallis H-test) as the temporal $\mathrm{CH}_{4}$ values neither achieved homogeneity of variances (Levene's Test for Equality of Variances; $p<0.05$ ) nor exhibited normal distribution (Kolmogorov-Smirnov Test; $\mathrm{p}<0.05$ ). On the other side, importance of various environmental variables including soil, water and vegetation in regulating temporal $\mathrm{CH}_{4}$ emissions, was assessed by conducting Pearson correlation matrix analysis. All statistical work was performed in SPSS-12.0 statistical software for Windows.

\section{Results and Discussion}

\section{CH4 flux measurements}

The annual averaged $\mathrm{CH}_{4}$ emissions from each zone of the Okhla reservoir were estimated by integrating the daily emissions throughout the year for each zone which were then extrapolated to the maximum reservoir inundated area of 370 hectares in order to compare with previous estimates. Pre-impoundment and post-impoundment $\mathrm{CH}_{4}$ fluxes were found to about $61.13 \mathrm{mgm}^{-2} \mathrm{~d}^{-1}$ and $233.09 \mathrm{mgm}^{-2} \mathrm{~d}^{-1}$ respectively.

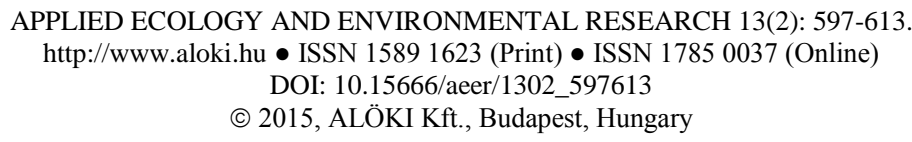


Results for reservoir $\mathrm{CH}_{4}$ flux values are summarized in Table 2. It was opined from the results that the Okhla reservoir exhibited the high degree of temporal variability in $\mathrm{CH}_{4}$ emissions as the summer season showed significantly higher $\mathrm{CH}_{4}$ flux (Kruskal-Wallis H-Test; $\mathrm{p}=0.000<0.05$ for ESZ and $\mathrm{p}=0.005<0.05 \mathrm{WZ}$ ) followed by monsoon season and least during winter season in both the zones. High $\mathrm{CH}_{4}$ flux during summer season can be corroborated by high temperature which results in increased decomposition rates leading to more reduced and anoxic conditions. Enhanced above ground plant biomass, low WD and DO, high Eh and BOD on the advent of summer season further support high $\mathrm{CH}_{4}$ flux values observed during summer season in comparison to monsoon and winter season.

Table 2. $\mathrm{CH}_{4}$ flux (value \pm standard error of mean) estimated for Okhla reservoir

\begin{tabular}{|c|c|c|c|c|c|}
\hline \multicolumn{6}{|c|}{ Pre -impoundment $\mathrm{CH}_{4}$ Flux $\left(\mathrm{mgm}^{-2} \mathrm{~d}^{-1}\right)^{*}$} \\
\hline $\begin{array}{l}\text { Wetland } \\
\text { zone }\end{array}$ & $\begin{array}{l}\text { Monsoon } \\
2010\end{array}$ & Winter 2011 & $\begin{array}{l}\text { Summer } \\
2011\end{array}$ & $\begin{array}{l}\text { Annual } \\
\text { mean value }\end{array}$ & $\begin{array}{l}\text { Total } \\
\text { wetland } \\
\text { area **** } \\
\text { (Hectares) }\end{array}$ \\
\hline $\begin{array}{l}\text { ESZ } \\
\text { (Exposed } \\
\text { soil zone) }\end{array}$ & $26.17 \pm 3.59$ & $10.71 \pm 0.84$ & $\begin{array}{l}137.77 \pm \\
11.92\end{array}$ & $\begin{array}{l}61.13 \pm \\
13.41\end{array}$ & 370.00 \\
\hline \multicolumn{6}{|c|}{ Post -impoundment $\mathrm{CH}_{4}$ Flux $\left(\mathrm{mgm}^{-2} \mathrm{~d}^{-1}\right)^{* *}$} \\
\hline $\begin{array}{l}\text { SWZ***** } \\
\text { (Shallow } \\
\text { water zone) }\end{array}$ & $\begin{array}{l}105.73 \pm \\
44.63\end{array}$ & $92.53 \pm 22.79$ & $\begin{array}{l}431.25 \pm \\
48.38\end{array}$ & $\begin{array}{l}209.84 \pm \\
39.49\end{array}$ & 240.50 \\
\hline \multirow[t]{2}{*}{$\begin{array}{l}\text { DWZ****** } \\
\text { (Deep water } \\
\text { zone) }\end{array}$} & $19.20 \pm 2.97$ & $17.47 \pm 3.49$ & $33.42 \pm 1.92$ & $23.25 \pm 2.52$ & 129.50 \\
\hline & & & $\begin{array}{l}\text { Total } \mathrm{CH}_{4} \\
\text { flux from } \\
\text { WZ }\end{array}$ & 233.09 & 370.00 \\
\hline
\end{tabular}

*Pre-impoundment CH4 Flux was represented by ESZ

***ost-impoundment CH4 Flux was represented by WZ (SWZ+DWZ)

***Total wetland area for Okhla Reservoir is 400 hectares but only 370 hectares has been included in CH4 emission estimation excluding 30 hectares which mainly comprise of roads and bunds (Management plan for Okhla Bird Sanctuary, 2011-2021)

****Area covered by the SWZ was about $65 \%$ of total wetland area (Manral et al., 2012)

*****Area covered by the DWZ was about $35 \%$ of total wetland area (Manral et al., 2012)

It was also observed that the flooding of landscape to create reservoir triggers the $\mathrm{CH}_{4}$ generation largely because of anaerobic decomposition of the terrestrial soils and plants inundated during impoundment. Different landscapes contain different amounts of stored organic carbon in soils and vegetation (Schlesinger, 1997), and so the potential for $\mathrm{CH}_{4}$ production and loss varies from site to site characteristics (St. Louis et al., $2000)$. In the present investigation, high soil organic carbon $(0.83 \pm 0.005 \%)$ and above ground plant biomass $\left(36.47 \pm 6.06 \mathrm{~g} \mathrm{DW} \mathrm{m}^{-2}\right)$ estimated in the exposed soil of Okhla reservoir represents the most probable source of labile organic carbon for $\mathrm{CH}_{4}$ 
generation before flooding. Results showed that this carbon stock further increased after impoundment due to the surplus organic load contributed by river's inflow water as total organic carbon $\left(20.06 \pm 1.04 \mathrm{mg} \mathrm{l}^{-1}\right)$, and macrophytic vegetation as aquatic plant biomass $\left(16.81 \pm 2.74 \mathrm{~g} \mathrm{DW} \mathrm{m}^{-2}\right)$ supporting the total $\mathrm{CH}_{4}$ flux of $233.09 \mathrm{mg} \mathrm{m}^{-2} \mathrm{~d}^{-1}$. Thus, the post-impoundment $\mathrm{CH}_{4}$ flux was higher than pre-impoundment $\mathrm{CH}_{4}$ flux with a net contribution of $171.96 \mathrm{mg} \mathrm{m}^{-2} \mathrm{~d}^{-1}$. The net $\mathrm{CH}_{4}$ emissions from Okhla reservoir $\left(171.96 \mathrm{mg} \mathrm{m}^{-2} \mathrm{~d}^{-1}\right)$ exceeded the value of $83.80 \mathrm{mg} \mathrm{m}^{-2} \mathrm{~d}^{-1}$ estimated for a eutrophic reservoir by Gunkel (2009) but was below the value of $300 \mathrm{mg} \mathrm{m}^{-2} \mathrm{~d}^{-1}$ reported by St. Louis et al. (2000) for tropical reservoirs.

In addition, in comparison with the other estimates (Table 3), Okhla reservoir exhibits significantly higher mean $\mathrm{CH}_{4}$ flux values $\left(116.60 \mathrm{mg} \mathrm{m}^{-2} \mathrm{~d}^{-1}\right)$ after flooding owing to i) excessive input of the allochthonous organic carbon from surrounding areas through Yamuna and Hindon river as indicated by high BOD $\left(21.50 \pm 1.31 \mathrm{mg} \mathrm{l}^{-1}\right)$ and TOC values $\left(20.06 \pm 1.04 \mathrm{mg} \mathrm{l}^{-1}\right)$, ii) enhanced autochthonous organic carbon production by heavy aquatic vegetation infestation in the lake, and iii) high percentage of low water depth non-stratified shallow areas (nearly $65 \%$ of total wetland area) contributing about $90.03 \%$ of total post-impoundment $\mathrm{CH}_{4}$ flux whereas DWZ emits only $9.97 \%$ of total post-impoundment $\mathrm{CH}_{4}$ flux occupying the only $35 \%$ of total wetland area. However, total surface emissions after integrating the point measurements to the entire water surface of the reservoir, $\mathrm{CH}_{4}$ flux values for Petit Saut, Balbina, Lokka, Laforge 1, Shasta, Three Gorges reservoir exceeded the $\mathrm{CH}_{4}$ emissions obtained for Okhla reservoir mainly due to the large surface areas.

Table 3. Air-water interface $\mathrm{CH}_{4}$ flux for Okhla and some other important reservoirs

\begin{tabular}{|c|c|c|c|c|c|c|c|}
\hline Reservoir & Country & Climate & $\begin{array}{l}\text { Area } \\
\text { (hectares) }\end{array}$ & $\begin{array}{l}\text { Mean } \\
\text { depth (m) }\end{array}$ & $\begin{array}{l}\text { Mean } \mathrm{CH}_{4} \\
\text { flux } \\
\left(\mathrm{mgm}^{-2} \mathrm{~d}^{-1}\right)\end{array}$ & $\begin{array}{l}\text { Area-wise } \\
\mathrm{CH}_{4} \quad \text { flux } \\
\text { (tones } \mathrm{yr}^{-1} \text { ) }\end{array}$ & Reference \\
\hline Tsengwen & Taiwan & Tropical & 1772 & 34.5 & 5.95 & 38.5 & Wang et al. (2013) \\
\hline Petit Saut & France & Tropical & 28750 & 10.0 & 44.80 & 4701.2 & Guerin et al. (2006) \\
\hline Balbina & Brazil & Tropical & 1960 & 7.4 & 33.60 & 240.4 & Guerin et al. (2006) \\
\hline Samuel & Brazil & Tropical & 419.5 & 5.7 & 80.00 & 122.5 & Guerin et al. (2006) \\
\hline Lokka & Finland & Boreal & 41700 & 7.4 & 33.60 & 5114.1 & $\begin{array}{l}\text { Huttunen et al. } \\
(2003) ; \text { Y. Zhao et al. } \\
(2013)\end{array}$ \\
\hline Laforge 1 & Canada & Boreal & 128800 & 3.0 & 27.36 & 12862.5 & $\begin{array}{l}\text { Tremblay et al. } \\
(2005) \text {; Y. Zhao et al. } \\
(2013)\end{array}$ \\
\hline Dworshak & $\begin{array}{l}\text { United } \\
\text { States }\end{array}$ & Temperate & 3700 & 65.0 & 4.40 & 59.4 & Soumis et al. (2004) \\
\hline Shasta & $\begin{array}{l}\text { United } \\
\text { states }\end{array}$ & Temperate & 7700 & 35.8 & 9.50 & 267.0 & Soumis et al. (2004) \\
\hline $\begin{array}{l}\text { Gold } \\
\text { Creek } \\
\text { Dam }\end{array}$ & Australia & Subtropical & 19 & 11.8 & 93.50 & 6.5 & Sturm et al. (2013) \\
\hline Three & China & Subtropical & 108400 & 70.0 & 5.12 & 2025.8 & Y. Zhao et al. (2013) \\
\hline \multicolumn{8}{|l|}{ Gorges } \\
\hline Liyutan & Taiwan & Subtropical & 449 & 49.0 & 4.80 & 7.9 & Wang et al. (2013) \\
\hline Okhla & India & Tropical & 370 & 2.0 & 116.60 & 157.5 & $\begin{array}{l}\text { Present study (post- } \\
\text { impoundment } \mathrm{CH}_{4} \\
\text { flux) }\end{array}$ \\
\hline
\end{tabular}




\section{Factors controlling CH4 flux}

It is amply clear from the present investigation and other reported studies that the $\mathrm{CH}_{4}$ emission potential in reservoirs is highly site specific and varies with particular reservoir characteristics such as surface area, age, water residence time, physicochemical properties of river's inflow water, soil quality and type of vegetation being submerged during the progressive impoundment or being present in and around the reservoir after impoundment.

\section{Reservoir age, area and water retention time}

Newly constructed and large reservoirs are expected to release more $\mathrm{CH}_{4}$ as compared to older and small reservoirs. The most probable cause for this observation is that newly flooded labile carbon (present in plant leaves and litter) decompose at a higher rate as compared to older more recalcitrant organic carbon including soil organic carbon (SOC). But the present study showed that it is complicated to quantify flux-age and flux-area relationship in the reservoirs like Okhla reservoir where most of the reservoir area is shallow and occupied by heavy macrophytic vegetation.

In Okhla reservoir, dense macrophytic vegetation in shallow areas, floating vegetation in deeper areas and dense terrestrial vegetation present along reservoir periphery facilitates the continuous supply of fresh labile carbon to methanogens. Thus, though the Okhla reservoir is older $(\sim 24$ yrs.) and occupies the small flooded area of 370 hectares, it produces a substantial amount of $\mathrm{CH}_{4}$ independent of age and area. So, these two parameters were not found to be the sole controlling factors for $\mathrm{CH}_{4}$ production and emission in case of Okhla reservoir. Sturm et al. (2013) also mentioned that the older reservoir examined in south east Queensland exhibited higher $\mathrm{CH}_{4}$ emission rates than younger reservoirs suggesting that reservoir age is not a key parameter for controlling $\mathrm{CH}_{4}$ flux.

Water retention time is another important morphometric characteristic which significantly determines the rate of $\mathrm{CH}_{4}$ production within the reservoir. Fearnside (2005) expressed that the longer the water retention time, lower the oxygen concentration in the reservoir leading to enhanced $\mathrm{CH}_{4}$ production. Thus, reservoir with long retention time like Okhla reservoir (water retention time $\sim 12$ months) is prone to high nutrient/organic loadings and remained anoxic almost throughout the year supporting high rates of $\mathrm{CH}_{4}$ production.

\section{Floral composition}

Twenty important plant species (including aquatic, semi-aquatic and terrestrial species) have been identified in all the three zones (SWZ, DWZ and ESZ) of Okhla reservoir (Table 4). The total above-ground plant biomass/aquatic plant biomass (Table 5) was also estimated to find out the role of vegetation in controlling the $\mathrm{CH}_{4}$ emission rates. It was observed that high plant mediated $\mathrm{CH}_{4}$ flux due to the presence of dense vegetation (aquatic and terrestrial) at Okhla reservoir discriminate this reservoir from many other tropical/subtropical reservoirs as most of the studied reservoirs include hydroelectric dams where $\mathrm{CH}_{4}$ emissions are either restricted by absence of aquatic vegetation or presence of limited aquatic vegetation.

Aquatic vegetation mainly regulates the $\mathrm{CH}_{4}$ emissions by providing easily degradable organic substrates to methanogens and by facilitating $\mathrm{CH}_{4}$ to move out of the water column to atmospheres via vascular transport. Floral composition analysis for 
Okhla reservoirs demonstrate that SWZ was heavily invaded by macrophytic vegetation including Eichhornia crassipes, Typha angustifolia, Pistia stratiotes etc. Eichhornia crassipies which is a most widespread floating fresh water plant is 4-11 times as active in $\mathrm{CH}_{4}$ emission as the rice paddies and release the bulk of $\mathrm{CH}_{4}$ from leaf blades and much less through the petiole (Banik et al., 1993; Rady, 1979). The large plant biomass of Eichhornia crassipies $\left(3.66 \pm 0.83 \mathrm{~g} \mathrm{DW} \mathrm{m}^{-2}\right)$ and Typha angustifolia $(4.04 \pm 0.70 \mathrm{~g}$ $\mathrm{DW} \mathrm{m}^{-2}$ ) on decomposition enrich the aquatic sediments with labile plant substrates for $\mathrm{CH}_{4}$ generation. Moreover, continuous semi-stagnant mats of Eichhornia crassipies (water hyacinth) with sediment- rooted emergent macrophytes including Alternanthera philoxeroides, Paspalum distichum, Alternanthera sessilis etc. present in shallow regions of reservoir periphery, also facilitate the increase in $\mathrm{CH}_{4}$ flux after flooding due to boosted $\mathrm{CH}_{4}$ vascular transport and additional aquatic plant biomass input of $16.81 \pm$ $2.74 \mathrm{~g} \mathrm{DW} \mathrm{m}^{-2}$.

Table 4. Flora identified at Okhla reservoir

\begin{tabular}{clllll}
\hline $\begin{array}{c}\text { Species } \\
\text { code }\end{array}$ & Botanical name & Family & $\begin{array}{c}\text { Species } \\
\text { code }\end{array}$ & Botanical name & Family \\
\hline A & Cyperus Sps. & Cyperaceae & $\mathrm{K}$ & Chenopodiummurale & Chenopodiaceae \\
$\mathrm{B}$ & Cynodon dactylon & Poaceae & $\mathrm{L}$ & Melochiacorchorifolia & Sterculiaceae \\
$\mathrm{C}$ & Oplismenus burmannii & Poaceae & $\mathrm{M}$ & Cannabis sativa & Cannabinaceae \\
$\mathrm{D}$ & Alternanthera sessilis & Amaranthaceae & $\mathrm{N}$ & Polygonum lanigerum & Polygonaceae \\
$\mathrm{E}$ & Sacchrum spontaneum & Poaceae & $\mathrm{O}$ & Xanthium strumarium & Asteraceae \\
$\mathrm{F}$ & Panicum sps. & Poaceae & $\mathrm{P}$ & Eich & Pontederiaceae \\
$\mathrm{G}$ & Lantana Indica & Verbenaceae & $\mathrm{Q}$ & Alternantheraphiloxeroides & Amaranthaceae \\
$\mathrm{H}$ & Kyllinga squamulata & Cyperaceae & $\mathrm{R}$ & Pistia stratiotes & Araceae \\
$\mathrm{I}$ & Paspalum distichum & Poaceae & $\mathrm{S}$ & Typha angustifolia & Typhaceae \\
$\mathrm{J}$ & Parthenium hysterophorus & Asteraceae & $\mathrm{T}$ & Ranunculussceleratus & Renunculaceae \\
\hline
\end{tabular}

Table 5. Plant biomass estimation for ESZ, SWZ and DWZ at Okhla reservoir

\begin{tabular}{|c|c|c|c|c|c|c|c|}
\hline \multirow{2}{*}{ Zone } & \multicolumn{2}{|l|}{ Monsoon-2010 } & \multicolumn{2}{|l|}{ Winter-2011 } & \multicolumn{3}{|l|}{ Summer-2011 } \\
\hline & $\begin{array}{l}\text { Floral } \\
\text { composition }\end{array}$ & $\begin{array}{l}\text { Total } \\
\text { biomass } * * * \\
\left(\text { g DW m }^{2}\right)^{* *}\end{array}$ & $\begin{array}{l}\text { Floral } \\
\text { composition }\end{array}$ & $\begin{array}{l}\text { Total } \\
\text { biomass } \\
\left(\text { g DW m }{ }^{2}\right)\end{array}$ & $\begin{array}{l}\text { Floral } \\
\text { composition }\end{array}$ & 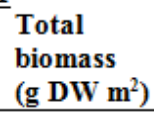 & $\begin{array}{l}\text { Annual } \\
\text { average* }\end{array}$ \\
\hline ESZ & $\begin{array}{l}\mathrm{A}, \mathrm{B}, \mathrm{C}, \mathrm{D}, \mathrm{E}, \mathrm{F}, \mathrm{G}, \\
\mathrm{H}, \mathrm{I}\end{array}$ & 38.18 & $\begin{array}{l}\mathrm{B}, \mathrm{C}, \mathrm{D}, \mathrm{E}, \mathrm{I}, \mathrm{J}, \\
\mathrm{K}, \mathrm{L}, \mathrm{M}\end{array}$ & 25.23 & $\begin{array}{l}\mathrm{B}, \mathrm{C}, \mathrm{D}, \mathrm{E}, \mathrm{J}, \mathrm{N}, \\
\mathrm{O}\end{array}$ & 46.01 & $36.47 \pm 6.06$ \\
\hline $\begin{array}{l}\text { SwZ } \\
\text { DWZ }\end{array}$ & $\mathrm{C}, \mathrm{I}, \mathrm{P}, \mathrm{Q}, \mathrm{R}, \mathrm{S}$ & 19.52 & $\begin{array}{r}C, D, F, P, T, S \\
\text { No veget }\end{array}$ & $\begin{array}{l}11.34 \\
\text { tion }\end{array}$ & $\mathrm{I}, \mathrm{P}, \mathrm{Q}, \mathrm{R}, \mathrm{S}$ & 19.57 & $16.81 \pm 2.74$ \\
\hline
\end{tabular}

* Annual mean value \pm standard error of mean, $* * \mathrm{~g} \mathrm{DW} \mathrm{m}^{2}=$ grams of dry weight per meter square, $* * *$ total plant biomass is equivalent to above ground plant biomass in ESZ (Exposed soil zone) and aquatic plant biomass in SWZ (Shallow water zone)/DWZ (Deep water zone)

In contrast, DWZ was devoid of macrophytic vegetation except few floating mats of Eichhornia crassipies which were not considered noteworthy in $\mathrm{CH}_{4}$ emissions. The plausible explanation for this observation is that the floating vegetation is not much efficient in $\mathrm{CH}_{4}$ vascular transport as they are not stagnant and their time of residence at one place was not enough to absorb and eliminate the substantial amounts of $\mathrm{CH}_{4}$ from the water column to the atmosphere. Consequently, $\mathrm{SWZ}$ released more $\mathrm{CH}_{4}$ than DWZ proving the observation of Singh et al. (2000) which vowed that vegetated water surface emits more $\mathrm{CH}_{4}$ than non-vegetated water surface. Thus, aquatic plant biomass show strong positive correlation of $\mathrm{r}=0.62 ; \mathrm{p}<0.01$ zone wise. Temporally, in SWZ, aquatic plant biomass exhibit comparatively weak correlation $(r=0.44 ; \mathrm{p}<0.05)$ with seasonal 
$\mathrm{CH}_{4}$ flux. This may be due the observation that monsoon and summer seasons displayed nearly similar aquatic plant biomass as both monsoon and summer seasons exhibit optimal conditions for plant growth including temperature, moisture content, nutrient availability etc. On the contrary, aquatic plant biomass was lowest during the winter season because of cold damage induced by low temperature (Table 5). No correlation was attempted for DWZ as it was devoid of sediment rooted macrophytic vegetation.

ESZ at Okhla reservoir was also densely occupied by various amphibious and terrestrial plants including Cynodon dactylon, Oplismenus burmannii, Alternanthera, sessilis, Sacchrum spontaneum etc. Vegetation of exposed soil chiefly affects the rates of $\mathrm{CH}_{4}$ production by determining the amount of plant litter that can be added directly or washed away from exposed soils to reservoir water during rainfall events. Therefore, to find out the contribution of vegetation of exposed soil to $\mathrm{CH}_{4}$ flux, above ground plant biomass was estimated. Results showed that vegetation present in exposed soils of Okhla provided organic matter in the form of above ground plant biomass of $36.47 \pm$ $6.06 \mathrm{~g} \mathrm{DW} \mathrm{m}^{-2}$ to support the high $\mathrm{CH}_{4}$ flux values observed at this reservoir. Above ground plant biomass showed positive correlation $(\mathrm{r}=0.83 ; \mathrm{p}<0.01)$ with seasonal $\mathrm{CH}_{4}$ flux. Enhanced above ground plant biomass provided increased availability of plant substrates for $\mathrm{CH}_{4}$ generating bacteria to support high $\mathrm{CH}_{4}$ flux values during summer season (Table 5).

\section{Soil and water quality of reservoir}

Soil and hydrological characteristics of Okhla reservoir were found to be in conformity with high $\mathrm{CH}_{4}$ flux values emitted by reservoir surface. It was observed that the metabolism of organic matter (allochthonous and autochthonous) is the primary source of $\mathrm{CH}_{4}$ emission within the reservoirs as the soil organic carbon (SOC) and total organic carbon (TOC) are the main indicators of high organic carbon loadings in the reservoirs. Annual mean values for SOC $(0.83 \pm 0.005 \%)$ at Okhla reservoir indicated that soil present at Okhla reservoirs are highly organic in nature and support pre/post impoundment $\mathrm{CH}_{4}$ production of $61.13 \mathrm{mg} \mathrm{m}^{-2} \mathrm{~d}^{-}$and $233.09 \mathrm{mg} \mathrm{m}^{-2} \mathrm{~d}^{-1}$ respectively. On the other hand, high TOC value $\left(20.06 \pm 1.04 \mathrm{mg} \mathrm{l}^{-1}\right)$ observed at Okhla reservoir was one of the key reasons for enhanced $\mathrm{CH}_{4}$ flux following the impoundment. High TOC values in Okhla reservoir can be attributed to the allochthonous organic carbon imported to reservoir through Yamuna and Hindon river tributaries and autochthonous organic matter produced by the dense macrophytic vegetation present in littoral zones of the reservoir.

SOC and TOC did not follow any significant seasonal trend with $\mathrm{CH}_{4}$ flux. SOC is a stable soil property which does not fluctuate seasonally. Amount of TOC in Okhla reservoir was primarily dependent on organic carbon imported to reservoir by Yamuna river that cannot be defined seasonally as Yamuna river receive polluted water from various non-point and point sources (Figure 3b, 4b, and 5c). Consequently, both SOC and TOC showed no significant correlations with seasonal $\mathrm{CH}_{4}$ emissions $(\mathrm{r}=-0.02$; $\mathrm{p}>0.05$ for $\mathrm{SOC}$ and $\mathrm{r}=-0.25 ; \mathrm{p}>0.05$ for TOC).

Data analysis in the present research also suggests that $\mathrm{CH}_{4}$ emission in tropical and subtropical reservoirs is also contingent on water depth (WD), dissolved oxygen (DO) and biological oxygen demand (BOD) content of the reservoir water. In Okhla reservoir, to find out the relationship between $\mathrm{CH}_{4}$ flux and $\mathrm{WD}, \mathrm{CH}_{4}$ estimation was carried out for shallow water zone (SWZ) and deep water zone (DWZ). Results brought out that that SWZ exhibited high $\mathrm{CH}_{4}$ flux values $\left(209.84 \pm 39.49 \mathrm{mg} \mathrm{m}^{-2} \mathrm{~d}^{-1}\right)$ than DWZ $(23.25$ 
$\left.\pm 2.52 \mathrm{mg} \mathrm{m}^{-2} \mathrm{~d}^{-1}\right)$ due to increased upward $\mathrm{CH}_{4}$ diffusion at low WD $(105.13 \pm 6.04$ $\mathrm{cm}$ ) and heavy macrophytic infestations leading to high plant mediated $\mathrm{CH}_{4}$ flux. In contrast, in stratified non-plant DWZ $(210.87 \pm 11.26 \mathrm{~cm})$, flux of $\mathrm{CH}_{4}$ from water surface to the atmosphere is highly constrained by high $\mathrm{CH}_{4}$ oxidation rates because of well-mixed oxygenated conditions prevalent in surface water and lack of aquatic vegetation. King (1990) and Laanbroek (2010) also reported that surface water is normally oxic and approximately $90 \%$ of $\mathrm{CH}_{4}$ emitted through diffusion and ebullition gets oxidized before reaching the atmosphere.

High $\mathrm{CH}_{4}$ flux values from Okhla reservoir are further supported by low DO (3.88 \pm $\left.0.24 \mathrm{mg} \mathrm{l}^{-1}\right)$ and high BOD $\left(20.51 \pm 0.90 \mathrm{mg} \mathrm{l}^{-1}\right)$ values as low DO values create anaerobic conditions and high BOD support high microbial activity for increased $\mathrm{CH}_{4}$ production rates in tropical/subtropical reservoirs. Similar relationship among $\mathrm{CH}_{4}$ flux, DO and BOD have also been reported by Das et al. (2005) for wetlands in the state of Orissa, India. In addition to this, negative Eh (redox potential) values $(-77.76 \pm 5.66 \mathrm{mV}$ for ESZ and varied from $-162.29 \pm 1.95 \mathrm{mV}$ to $-49.38 \pm 4.70 \mathrm{mV}$ for WZ) obtained at Okhla reservoir also support anaerobiosis leading to more reduced conditions and hence increased $\mathrm{CH}_{4}$ flux.

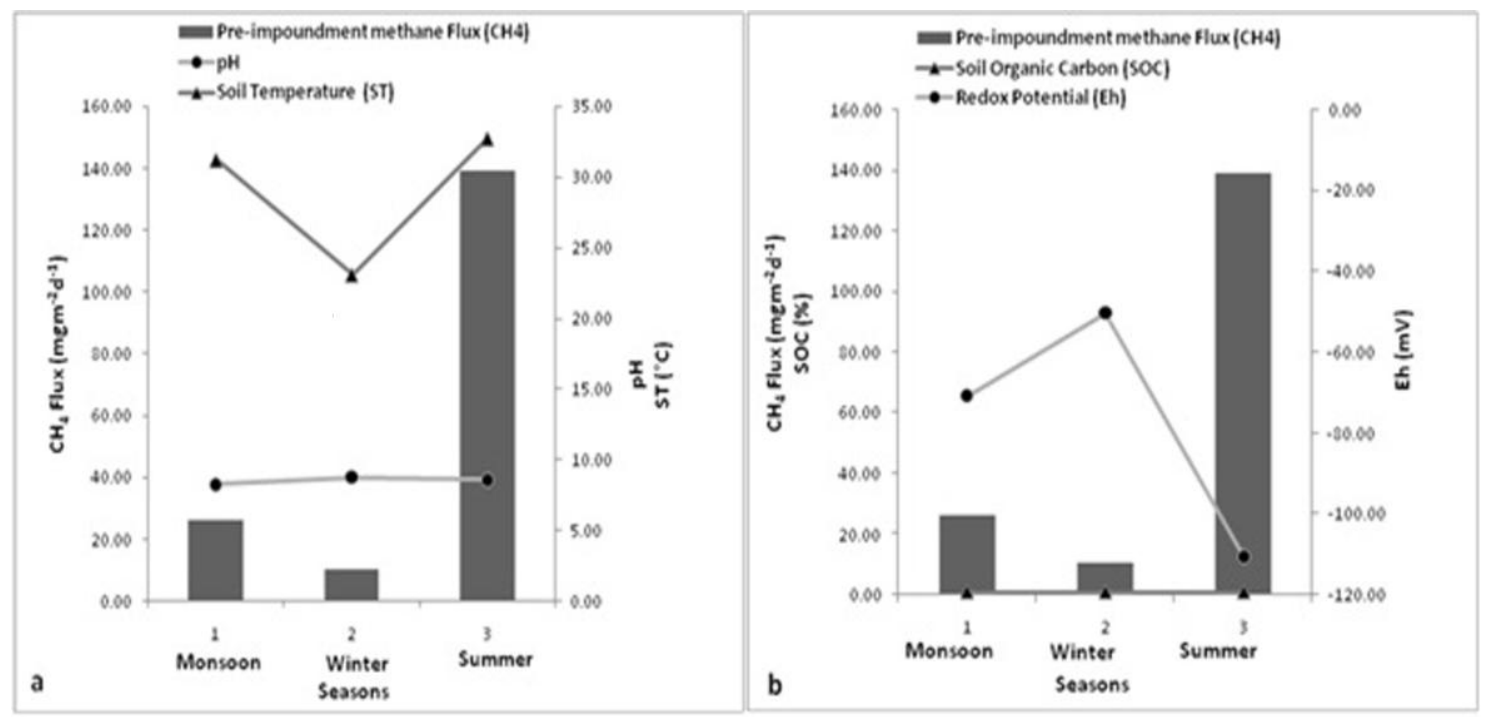

Figure 3. Temporal variability in pre-impoundment $\mathrm{CH}_{4}$ flux with respect to various soil quality parameters at Okhla reservoir

It can also be opined from the results that WD, DO and Eh were found to be negatively correlated $(\mathrm{r}=-0.70 ; \mathrm{p}<0.01$ for $\mathrm{WD} ; \mathrm{r}=-0.75 ; \mathrm{p}<0.01$ for $\mathrm{DO} ; \mathrm{r}=-0.93$; $\mathrm{p}<0.01$ for Eh in ESZ and $\mathrm{r}=-0.60 ; \mathrm{p}<0.01$ for $\mathrm{Eh}$ in WZ) and BOD was found to be positively correlated $(\mathrm{r}=0.73 ; \mathrm{p}<0.01)$ with seasonal $\mathrm{CH}_{4}$ flux supporting high $\mathrm{CH}_{4}$ flux values in summer season. High temperature in summer season supports high microbial activities. This will lead to enhanced decompositions of organic matter causing severe DO depletion, high Eh and BOD values. WD depth also falls down during summer season because of increased evaporation rates resulting in accelerated $\mathrm{CH}_{4}$ flux in summer season (Figure $4 a, 4 c, 5 a, 5 b$, and $5 c$ ).

The results of the current work have also shown that reservoir soil $\mathrm{pH}(8.57 \pm$ $0.05)$ and water $\mathrm{pH}(7.40 \pm 0.05-7.78 \pm 0.18)$ varied from neutral to alkaline 
range and lied within the optimum $\mathrm{pH}$ range for $\mathrm{CH}_{4}$ production i.e., 5.2 -9.2 (Buchanan and Gibbons, 1975; Banik et al., 1993). With respect to seasonal $\mathrm{CH}_{4}$ flux variations, soil $\mathrm{pH}$ and water $\mathrm{pH}$ exhibited insignificant correlation with $\mathrm{CH}_{4}$ emissions $(\mathrm{r}=-0.02 ; \mathrm{p}>0.05$ for soil $\mathrm{pH}$ and $\mathrm{r}=-0.18 ; \mathrm{p}>0.05$ for water $\mathrm{pH}$ ). Both soil $\mathrm{pH}$ and water $\mathrm{pH}$ remained constant throughout the year and showed no specific seasonal pattern (Figure $3 a, 4 c$, and $5 c$ ).

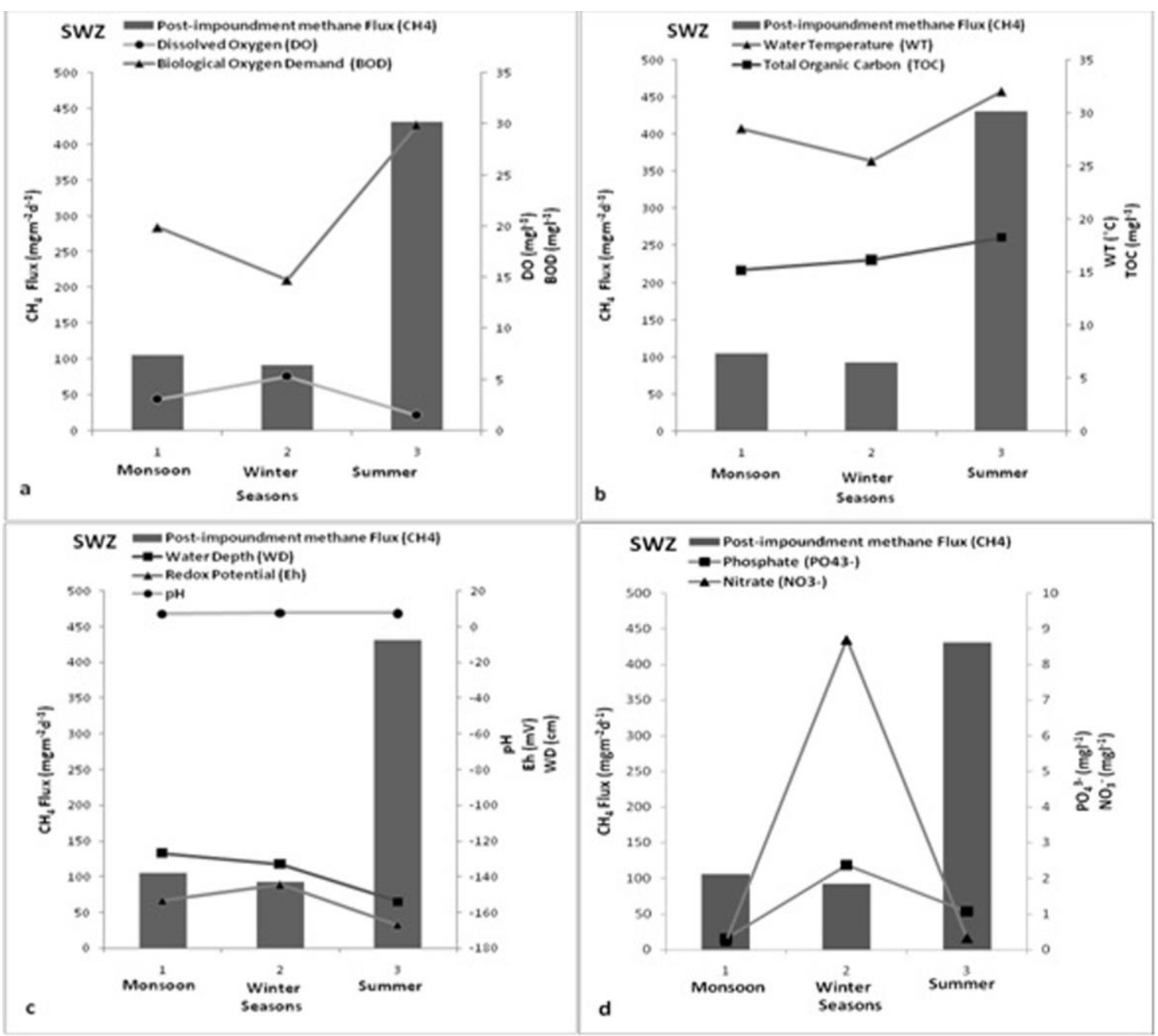

Figure 4. Temporal variability in post-impoundment $\mathrm{CH}_{4}$ flux with respect to various water quality variables in Shallow water zone (SWZ) at Okhla reservoir

Soil temperature (ST) and water temperature (WT) were also found within the congenial range for methanogenesis $\left(25^{\circ} \mathrm{C}-35^{\circ} \mathrm{C}\right.$; Wassman et al., 1998; Dubey, 2005) as mean values for ST and WT were about $28.83 \pm 1.10{ }^{\circ} \mathrm{C}$ and $28.34 \pm 0.68{ }^{\circ} \mathrm{C}$ respectively. Seasonally, both ST and WT were found to be positively correlated with $\mathrm{CH}_{4}$ flux ( $\mathrm{r}=0.68 ; \mathrm{p}<0.01$ for $\mathrm{ST}$ and $\mathrm{r}=0.49 ; \mathrm{p}<0.01$ for WT) due the direct simulation of methanogenic activity at high temperatures in summer season leading to enhanced $\mathrm{CH}_{4}$ emission rates (Figure $3 a, 4 b$, and $5 a$ ). 
Reservoir water also exhibited high annual mean concentrations of nutrients including $\mathrm{PO}_{4}{ }^{3-}\left(1.29 \pm 0.14 \mathrm{mg} \mathrm{l}^{-1}\right)$ and $\mathrm{NO}_{3}{ }^{-}\left(4.23 \pm 0.87 \mathrm{mg} \mathrm{l}^{-1}\right)$ indicating existence of eutrophic conditions in the reservoir. These nutrients primarily enter the reservoir through river's inflow water enriched in domestic, agricultural and industrial wastes. Addition of excess nutrients mainly results in high biomass production particularly in the form of dense macrophytic growth. Thus, high nutrient levels further support high $\mathrm{CH}_{4}$ flux in a eutrophic Okhla reservoir due to accelerated plant productivity. Seasonally, $\mathrm{PO}_{4}{ }^{3-}$ showed insignificant correlation with $\mathrm{CH}_{4}$ flux $(\mathrm{r}=-0.14 ; \mathrm{p}>0.05)$ as the $\mathrm{PO}_{4}{ }^{3-}$ content of $\mathrm{WZ}$ remained nearly stable throughout the year with slightly higher concentration during winter season. On the other hand, $\mathrm{NO}_{3}{ }^{-}$was found to be negatively but weakly correlated with seasonal $\mathrm{CH}_{4}$ flux $(\mathrm{r}=-0.36$; $\mathrm{p}<0.05)$. This may be due the reason that $\mathrm{NO}_{3}{ }^{-}$content was found to be higher in the winter season but during monsoon and summer season $\mathrm{NO}_{3}{ }^{-}$content was almost same (Figure $4 d$ and $5 d$ ).

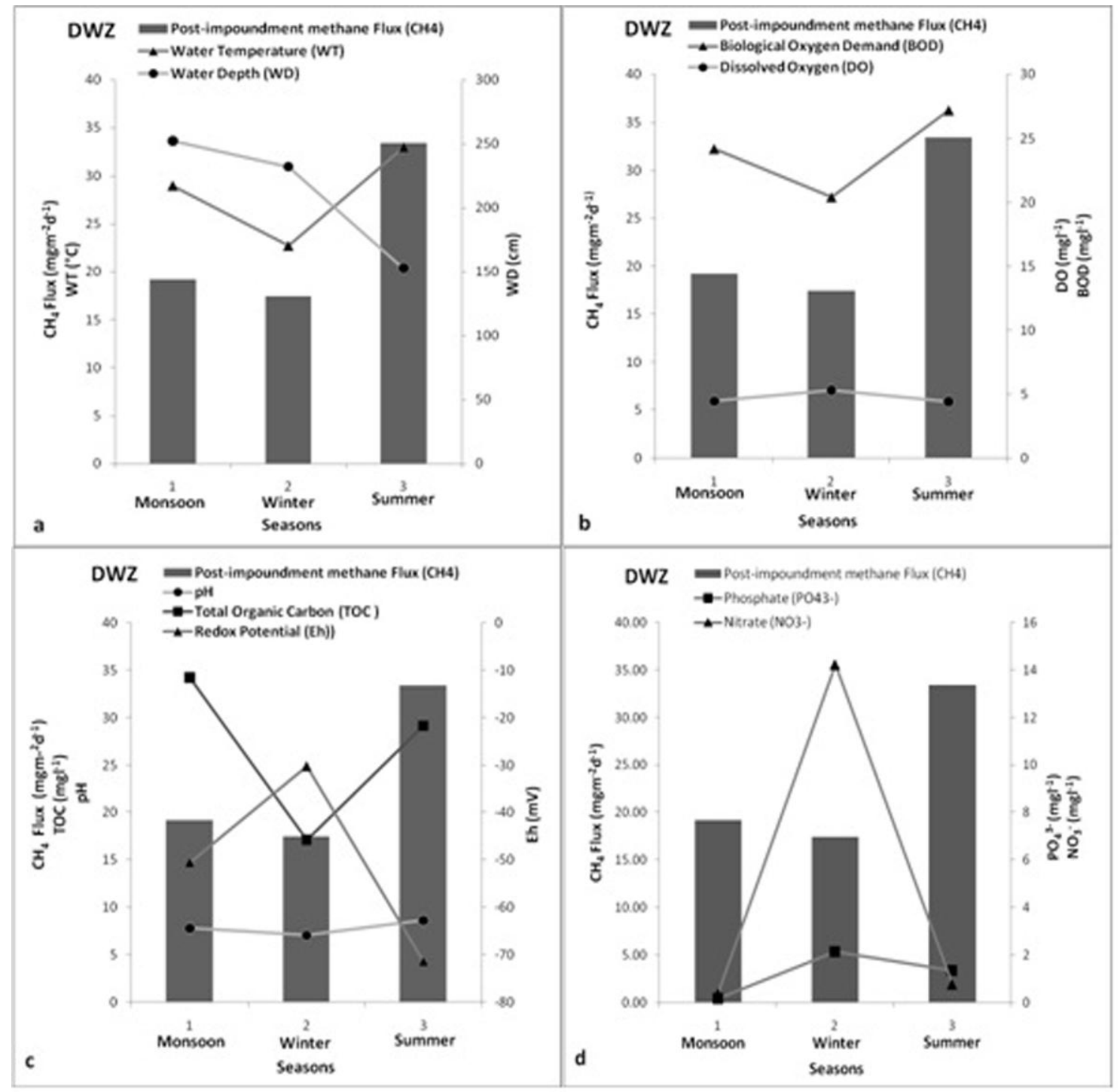

Figure 5. Temporal variability in post-impoundment CH4 flux with respect to various water quality variables in Deep water zone (DWZ) at Okhla reservoir 
Maximum $\mathrm{NO}_{3}{ }^{-}$and $\mathrm{PO}_{4}{ }^{3-}$ loadings during winter season might be due to the discharge of nutrient rich untreated wastewater into the reservoir from the unidentified non-point source (industrial units) as Okhla reservoir is surrounded by the Okhla industrial area. In addition to this, $\mathrm{NO}_{3}{ }^{-}$content increases during winter due to enhanced contribution from nitrogen rich sediments under high oxygen status during winter season. Contrary, $\mathrm{NO}_{3}{ }^{-}$values during monsoon and summer season were principally low because of increased biotic utilization by macrophytes.

\section{Conclusions and future outlook}

Present research work has brought out vividly that the Okhla reservoir represents a strong $\mathrm{CH}_{4}$ emission source as the emissions from this reservoir far exceeded the $\mathrm{CH}_{4}$ flux values reported for a eutrophic and other temperate, boreal, sub-tropical and tropical reservoirs. Higher $\mathrm{CH}_{4}$ emissions are attributed to long water retention time, enhanced organic and nutrient loadings from Yamuna and Hindon river, high primary productivity especially macrophytes and high percentage of low depth shallow areas. The $\mathrm{CH}_{4}$ emissions in Okhla reservoir exhibits a significant seasonal trend with maximum emissions during summer season and minimum during winter season in line those reported for various other tropical and subtropical reservoirs. This was due to the occurrence of suitable conditions of temperature, Eh, DO, BOD, WD and plant biomass during summer season.

In conclusion, this study demonstrated that the tropical/subtropical shallow reservoirs heavily infested with aquatic vegetation (like Okhla reservoir) can contribute significant amounts (171.96 mg m $\mathrm{mg}^{-2} \mathrm{~d}^{-1}$ ) of $\mathrm{CH}_{4}$ to the atmosphere after flooding. Thus, for sustainable use of tropical/subtropical reservoirs, $\mathrm{CH}_{4}$ emission estimation from these reservoirs should constitute an integral part of environmental impact assessment studies prior to construct any reservoir in the hot tropical and subtropical areas. Further, based on this study some of the important management strategies can be adopted for regulating $\mathrm{CH}_{4}$ emissions in tropical and subtropical reservoirs: 1) Assessment of total carbon stock (soil organic carbon and plant biomass), organic and pollutant loadings of inflow water and $\mathrm{CH}_{4}$ production potential of reservoir area before submersion, 2) Maintenance of oligotrophic conditions in the reservoir after submersion by upholding appropriate water depth, checking growth of highly proliferating aquatic weeds including Eichhornia crassipes and Typha angustifolia, and organic/pollutant load of water to be discharged into the reservoir after flooding. Therefore, considering the paucity of substantial $\mathrm{CH}_{4}$ emission data in tropical reservoirs, in future, $\mathrm{CH}_{4}$ flux data obtained in Okhla reservoir may be used as an indicator for planning appropriate management strategies to minimize the $\mathrm{CH}_{4}$ emissions from tropical and subtropical reservoirs.

Acknowledgements. Authors appreciate support from Mr. B.K. Patnaik, Principle Chief Conservator of Forest (Wildlife), Ministry of Environment and Forest, Lucknow, Uttar Pradesh, India for permission to collect the samples from protected areas (Bird Sanctuaries).The authors are immensely thankful to Dr. Nyan Ahmad, IARI, Pusa, Delhi for his assistance in soil texture analysis and Dr. Prabhat K. Gupta, National Physical Laboratory, Delhi for his valuable guidance in $\mathrm{CH}_{4}$ gas analysis. Authors also grateful to Dr. Ambrish and Dr. Manikandan, Botanical Survey of India, Dehradun for their help in identifying the flora, and Prof. Venkateshwar Shekhar, Visiting Faculty, Guru Gobind Singh Indraprastha University, Delhi for his kind support in statistical analysis. 


\section{REFERENCES}

[1] APHA. (2005): Standard Methods for examination of water and waste water, 19th ed. Water Environment Federation, American Water Works Association (AWWA), Water Pollution Control Federation, Washington, DC, USA.

[2] Banik, A.; Sen, M.; Sen, S.P. (1993): Methane emissions from waterhycinth-infested freshwater ecosystems. - Chemosphere 27(8): 1539-1552.

[3] Bastviken, D.; Tranvik, L.J.; Downing, J.A.; Crill, P.M.; Enrich-Prast, A. (2011): Freshwater Methane Emissions Offset the Continental Carbon Sink. - Science 331: 50.

[4] Buchanan, R.E.; Gibbons, NE. (eds.) (1975): Bergey,s Manual of Determinative Bacteriology, 8th Edition, Williams and Wilkins Co., Baltimore.

[5] Chakraborty, M.; Sharma, C.; Pandey, J.; Singh, N.; Gupta, PK. (2011): Methane emission estimation from landfills in Delhi: A comparative assessment of different methodologies. - Atmospheric Environment 45: 7135-42.

[6] Das, S.N.; Das, R.; Thakur, R.S. (2005): Estimation of methane emitted by natural wetlands of Orissa: Based on case studies on three representative wetlands. Toxicological and Environmental Chemistry 87(3): 351-363.

[7] Dubey, S.K. (2005): Microbial ecology of methane emission in rice agroecosystem: a review. - Applied Ecology and Environmental Research 3(2): 1-27.

[8] Fearnside, P.M. (2005): Brazil's Samuel dam: Lessons for hydroelectric development policy and the environment in Amazonia. - Environmental Management 35(1): 1-19.

[9] Guerin, F.; Abril, G.; Richard, S.; Burban, B.; Reynouard, C.; Seyler, P.; Delmas, R. (2006). Methane and carbon dioxide emissions from tropical reservoirs: Significance of downstream rivers. - Geophysical Research Letters 33: L21407. DOI:10.1029/2006GL027929.

[10] Gunkel, G. (2009): Hydropower - A Green Energy? Tropical Reservoirs and Greenhouse Gas Emissions. - Clean 37(9): 726-734.

[11] Huttunen, J.T.; Alm, J.; Liikanena, A.; Juutinen, S.; Larmola, T.; Hammer, T.; Silvola, J.; Martikainen, P.J. (20030: Fluxes of methane, carbon dioxide and nitrous oxide in boreal lakes and potential anthropogenic effects on the aquatic greenhouse gas emissions. Chemosphere 52: 609-621.

[12] Karin Grandin. (2012): Variations of CH4 emissions within and between hydroelectric reservoirs in Brazil. Master's thesis, Department of Ecology and Evolution, Uppsala University, Sweden.

[13] Kemenes, A.; Forsberg, B.R.; Melack, J.M. (2011): CO2 emissions from a tropical hydroelectric reservoir (Balbina, Brazil). - Journal of Geophysical Research 116: G03004. DOI:10.1029/2010JG001465.

[14] Khoiyangbam, R.S.; Ganesh, S.; Singh, G. (2008): Evaluation of methane emissions from urban wetlands in Jhansi, Uttar Pardesh. Proceedings of Taal 2007: The 12th World Lake Conference, 1114-1121.

[15] King, G.M. (1990): Dynamics and control of methane oxidation in Danish wetland sediment. - FEMS Microbiology Ecology 74: 309-323.

[16] Laanbroek, J., Hendrikus. (2010): Methane emission from natural wetlands: interplay between emergent macrophytes and soil microbial process. A mini-review. - Annals of Botany 105: 141-153.

[17] Mallick, S.; Dutta, V. (2009): Estimation of Methane Emissions from North-Indian Subtropical Wetland. - Journal of Sustainable Development 2(2): 125-131.

[18] Management Plan for Okhla Bird Sanctaury. (2011 to 2021): Wildlife Institute of India, Dehradun and additional inputs from UP government: B.K. Patnaik (Chief Wildlife Warden, U.P.), Neeraj Kumar (Deputy Conservator of Forests, National Chambal Sanctaury Project, U.P.), and B. Prabhakar (Director, Horticulture, Noida, U.P.).

[19] Manral, U.; Raha, A.; Solanki, R.; Hussain, S.A.; Mohan, D.; Talukdar, G.; Veeraswami, G.G. (2012): Hydrological characteristics and flood plain vegetation of human impacted 
wetlands: A case study from Okhla Bird Sanctaury, National Capital Region, India. Asian Journal of Conservation Biology 2: 110-119.

[20] Narvenkar, G.; Naqvi, S.W.A.; Kurian, S.; Shenoy, D.M.; Pratihary, A.K.; Naik, H.; Patil, S.; Sarkar, A.; Gauns, M. (2013): Dissolved methane in Indian freshwater reservoirs. Environmental Monitoring and Assessment DOI:10.1007/s10661-013-3079-5.

[21] Purvaja, R.; Ramesh, R.; Frenzel, P. (2004): Plant-mediated methane emission from an Indian mangrove. - Global Change Biology 10: 1825-1834.

[22] Rady, H.M. (1979): Dangers and utilization of the Waterhyacinths. In Land, H.R., (ed.). Plant Research and Development. Institute for Scientific Cooperation, Tubingen, Germany, 10: 46-52.

[23] Rajkumar, A.N.; Barnes, J.; Ramesh, R.; Purvaja, R.; Upstill-Goddard, R.C. (2008): Methane and Nitrous oxide fluxes in the polluted Adyar River and estuary, SE India. Marine Pollution Bulletin 56: 2043-2051.

[24] Schlesinger, W.H. (1997): Biogeochemistry: An Analysis of Global Change. San Diego: Academic Press.

[25] Singh, D.; Chhonkar, P.K.; Pandey, R.N. (1999): Soil, plant and water analysis - A method manual. IARI, New Delhi.

[26] Singh, J.S.; Raghubanshi, A.S.; Reddy, V.S.; Singh, S.; Kashyap, A.K. (1998): Methane flux from irrigated paddy and dryland rice fields, and from seasonally dry tropical forest and Savanna soils of India. - Soil Biology and Biochemistry 30(2): 135-139.

[27] Singh, S.N.; Kulsheshtha, K.; Agnihotri, S. (2000): Seasonal dynamics of methane emissions from wetlands. - Chemosphere Global Change Science 2: 39-46.

[28] Soumis, N. ; Duchemin, E. ; Canuel, R. ; Lucotte, M. (2004) : Greenhouse gas emissions from reservoirs of the western United States. - Global Biogeochemical Cycles 18: GB3022. DOI: 10.1029/2003GB002197.

[29] St. Louis, V.L.; Kelly, C.A.; Duchemin, E.; Rudd, J.W.M.; Rosenberg, D.M.; (2000): Reservoir surfaces as sources of greenhouse gases to the atmosphere: A Global Estimate. Bioscience 50(9): 766-775.

[30] Sturm, K.; Yuan, Z.; Gibbes, B.; Grinham, A. (2013): Methane and nitrous oxide sources and emissions in a subtropical freshwater reservoir, south east Queensland, Australia. Biogeosciences Discussions 10: 19485-19508.

[31] Tremblay, A.; Therrien, J.; Hamlin, B.; Wichmann, E.; LeDrew, L.J. (2005): GHG emissions from boreal reservoirs and natural aquatic ecosystems. - In: Tremblay A, Varfalvy L, Roehm C, and Garneau M. (Eds.) Greenhouse Gas Emissions, Fluxes and Processes, Springer, New York, 209-232.

[32] Verma, A.; Subramanian, V.; Ramesh, R. (2002): Methane emissions from a coastal lagoon: Vembanad Lake, West Coast, India. - Chemosphere 47: 883-889.

[33] Walkely, A.J.; Black, I.A. (1934): Estimation of soil organic carbon by the chromic acid titration method. - Soil Science 37: 29-38.

[34] Wang, Y-H.; Huang, H-H.; Chu, C-P.; Chuag, Y-J. (2013): A preliminary survey of greenhouse gas emissions from three reservoirs in Taiwan. - Sustainable Environmental Research 23(3): 215-225.

[35] Wassmann, R.; Neue, H.D.; Bueno, C.; Latin, R.S.; Alberto, M.C.R.; Buendia, L.V.; Bronson, K.; Papen, H.; Rennenberg, H. (1998): Methane production capacities of different rice soils derived from inherent and exogenous substrates. - Plant and Soil 203: 227-237.

[36] Zhao, Y.; Wu, B.F.; Zeng, Y. (2013): Spatial and temporal patterns of greenhouse gas emissions from Three Gorges Reservoir of China. - Biogeosciences 10: 1219-1230. 